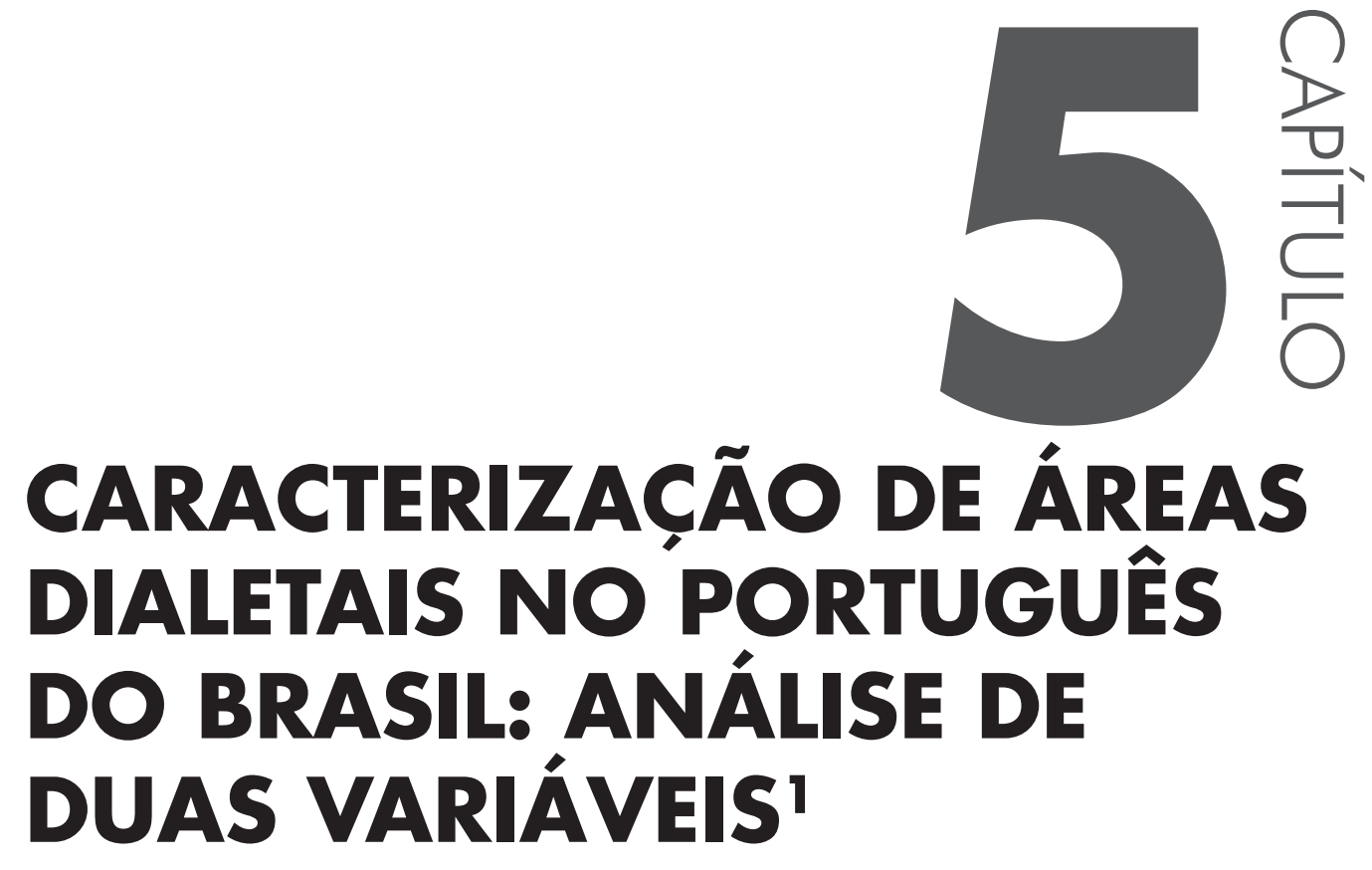

Dinah Isensee Callou Universidade Federal do Rio de Janeiro/CNPq

Silvia Figueiredo Brandão Universidade Federal do Rio de Janeiro/CNPq/FAPERJ

\title{
5.1 INTRODUC̣ÃO
}

A caracterização de áreas dialetais é tarefa das mais complexas, sobretudo no Brasil, pois, de um lado, nem sempre um conjunto de variáveis apresenta re-

1 Este texto constitui uma síntese, com algumas alterações, sobre duas variáveis comentadas por Brandão (2015) e Callou (2015); cf. Referências. 
sultados convergentes em determinadas áreas; de outro, as variantes que elas englobam por vezes se encontram representadas, com maior ou menor frequência, na fala de todo o país. Apesar dessas dificuldades, algumas variáveis vêm sendo apontadas como suscetíveis de propiciar, se não uma delimitação precisa, pelo menos uma macrodivisão linguística, com base em índices percentuais. Dentre elas, selecionaram-se, no que se refere ao vocalismo, a realização das vogais médias pretônicas, e, ao consonantismo, as possibilidades de concretização dos róticos nos distintos contextos em que ocorrem. A escolha de tais variáveis contempla, respectivamente, um caso de variação estável e outro de mudança em progresso, que, independentemente de suas implicações socioculturais e estruturais, ainda ensejam indicar algumas variantes como emblemáticas de determinadas regiões.

As análises que aqui se apresentam seguem o aparato teórico-metodológico da sociolinguística quantitativa laboviana, que permite estabelecer os condicionamentos linguísticos e sociais que atuam na distribuição diferenciada dos fenômenos por área geográfica, por gênero, por faixa etária e por nível de escolaridade. Tomam-se por base estudos realizados em diferentes regiões do país de modo a fornecer um quadro aproximado da diversidade linguística brasileira.

\subsection{AS VOGAIS MÉDIAS EM CONTEXTO PRETÔNICO}

Desde que Nascentes (1953) propôs a divisão do Brasil em duas grandes áreas linguísticas, a do Norte e a do Sul, com base na maior incidência, nesses falares, respectivamente, de concretizações médias abertas $[\varepsilon$ o ] e médias fechadas [e o] em contexto pretônico, diversos estudos têm sido realizados no sentido de melhor depreender os fatores que concorrem para essa diversificação.

Além da neutralização que reduz a cinco /a e i o u/ (CAMARA, JR, 1977; BISOL, 2003) - os segmentos capazes de gerar distinção significativa, atuam, nesse contexto, processos de harmonização e de redução vocálicas, o primeiro tendo como principal motivador a presença de vogal alta no contexto subsequente (em especial a vogal [i]), o último ora interpretado como condicionado foneticamente por consoantes [-coronais] adjacentes (BISOL, 1981; CALLOU; LEITE, 1986, 1991, entre vários outros), ora como um caso de mudança sem motivação aparente (BISOL, 2009), o que leva a outra interpretação, a de que a redução, gerada por alteamento, se difundiria por determinados itens lexicais, não necessariamente os mesmos em todas as áreas do país.

Lee; Oliveira (2003) demonstram que, na fala de Belo Horizonte, a vogal média posterior num mesmo contexto fônico - [t_m], [ $\_$k $]$, por exemplo - é produzida, em determinados vocábulos, como fechada ( $\mathrm{t}[\mathrm{o}] \mathrm{mada}, \mathrm{ch}[\mathrm{o}] \mathrm{cado})$ ou como alta ( $\mathrm{t}[\mathrm{u}]$ mate, ch[u]calho), de forma categórica. Além disso, mostram que a manutenção e o alteamento da média poderiam estar associados a uma especi- 
ficação semântica: assim, uma forma como fogão, quando se tratasse do eletrodoméstico, seria enunciada como $f[u] g a ̃ o$, quando remetesse a um fogaréu, seria sempre produzida como f[o]gão. Para Oliveira (1991, p. 104), toda mudança ocorreria por difusão lexical, conforme se observa na fórmula por ele enunciada ${ }^{2}$ :

as primeiras 'vítimas' de uma mudança sonora da forma $\mathrm{X} \rightarrow \mathrm{Y} / \mathrm{Z}$ são as palavras que apresentam os seguintes traços (não necessariamente nesta ordem):

a. X ocorre num nome comum;

b. Z oferece um contexto fonético natural para Y;

c. X é parte de uma palavra que ocorre em contextos informais de fala.

Ainda caracterizadores da complexidade que atinge as vogais médias, há casos de alteamento que incidem sobretudo na média anterior, de forma quase categórica. Brandão; Rocha; Santos (2012), examinado as vogais /e o/ em contexto inicial de vocábulo, na fala fluminense, demonstram que o alteamento dessa vogal obedece a um continuum, segundo a estrutura da sílaba em que se encontre, funcionando como gatilho para a implementação do processo a presença de $/ \mathrm{N} /$ - como em /eN/prego - ou /S/ - como em /eS/tranho - na posição de coda, conforme se verifica no Quadro 5.1. Os poucos casos de alteamento na estrutura \#V\$ como em lelvento - são condicionados, do ponto de vista estrutural, por ordem de importância, pela presença, em sílaba contígua, da vogal [i] (P. R. .77) ${ }^{3}$, como em [i]x[i]ste (existe) e da vogal [u] (P. R. .69), como em [i]d[u]cação (educação) e pela ocorrência de consoante alveolar sibilante a ela subsequente, como em [iz] ame (exame). Já a vogal posterior, nesses contextos, concretiza-se, de forma praticamente categórica, como média fechada.

Quadro 5.1 Continuum do alteamento de /e/ em contexto inicial de vocábulo, com base nos inputs de aplicação da regra

\begin{tabular}{|c|c|c|}
\hline \multicolumn{3}{|c|}{ 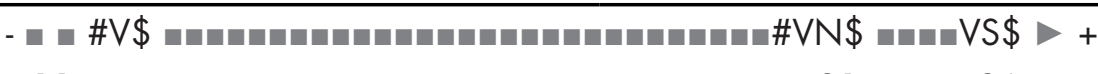 } \\
\hline .11 & .91 & 96 \\
\hline
\end{tabular}

Fonte: BRANDÃO; ROCHA; SANTOS, 2012.

A par dos mencionados condicionamentos estruturais a que se encontra sujeita a variação das vogais médias, verifica-se uma não menos significativa atuação de fatores vinculados a variáveis extralinguísticas, entre as quais a mais relevante - conforme já detectara Nascentes (op. cit.) - é de natureza diatópica, conforme se verá nas seções seguintes.

2 Tradução de Silvia F. Brandão.

3 P. R. refere-se a peso relativo. 


\subsubsection{Em falares do Sul e do Sudeste}

Foi Bisol (1981) quem primeiro focalizou, de forma sistemática, a harmonização e a redução vocálicas no âmbito das médias pretônicas com base em amostras representativas de quatro comunidades do Rio Grande do Sul. Mostrou-se relevante para o alteamento, além de determinadas fatores estruturais conjugados, a variável etnia (p. 261). Os indivíduos metropolitanos (Porto Alegre), que falam apenas português e, em segundo lugar, os de origem italiana (Monte Bérico, em Veranópolis) foram os que mais implementaram a regra, estes últimos em virtude de haver vogal alta no dialeto italiano em contextos paralelos ao da vogal média em português. Já os indivíduos bilíngues de origem alemã (Taquara) alteiam mais o /o/, o que ela atribui ao Umlaut, processo que, em alemão, incide sobre essa vogal, mas não sobre /e/. No que se refere aos falantes monolíngues da zona fronteiriça (Santana do Livramento), a regra atua em menor escala por influência do espanhol, "a língua românica que mais preservou a média pretônica latina” (p. 261)

Bisol observou, ainda, que o alteamento, embora não estigmatizado, por conta provavelmente da ortografia, mostrou-se menos produtivo entre os falantes cultos, sobretudo os mais jovens, o que seria indício de que a regra poderia estar regredindo (p. 261-262).

Em recente estudo sobre as médias em contexto pretônico, Rocha; Brandão (2015) procuram caracterizar, do ponto de vista geo-sociolinguístico, os falares do Sudeste com apoio em estudos realizados sobre a fala do Espírito Santo (CELIA, 2004, no Município de Nova Venécia), de Minas Gerais (ALMEIDA, 2008, em Machacalis; DIAS, 2008, em Ouro Branco e Piranga), da Região Metropolitana do Rio de Janeiro (YACOVENCO, 1993 e ROCHA, 2013, o primeiro sobre a fala culta carioca, o segundo sobre a fala do Município de Nova Iguaçu) e de São Paulo (SILVEIRA, 2008 e CARMO, 2009, ambos sobre São José do Rio Preto).

Com base no confronto das análises realizadas concluíram que, no Sudeste, predominam, em todos os falares, as variantes [e o], neles atuando os processos de harmonização e redução vocálicas, ressaltando que, apesar de as consoantes adjacentes se mostrarem relevantes para o processo de redução vocálica, os segmentos que podem atuar para o alteamento não coincidem em todas as comunidades, o que pressupõe haver fortes motivações de natureza lexical para a ocorrência do processo. Dentre as conclusões de natureza extralinguística, afirmam que:

(b) Do ponto de vista diatópico, observam-se aspectos divergentes que demonstram a maior complexidade da área geográfica mineira e, provavelmente da capixaba, frente às do Rio de Janeiro e de São Paulo, o que pressupõe a existência de diferentes áreas linguísticas, sobretudo no que tange ao primeiro dos mencionados estados.

O elemento diferenciador em relação à fala dessas localidades é a frequência das variantes médio- baixas. Em duas localidades de Minas Gerais (Machacalis e Piran- 


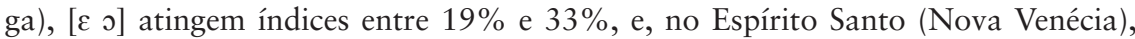
entre $14 \%$ e $20 \%$. Já na área metropolitana de Belo Horizonte (Ouro Branco), os índices ficam entre $3 \%$ e $11 \%$. No Rio de Janeiro esse índice cai drasticamente (na fala carioca culta e na de Nova Iguaçu, respectivamente, 3,9\% e 0,8\% para [ $[\varepsilon$ e e 4,2\% e $1,1 \%$ para [o]), circunscrevendo-se a determinados itens lexicais, enquanto em São Paulo (São José do Rio Preto), essas variantes não são registradas.

$[\ldots]$

(e) Do ponto de vista social, verifica-se, em alguns falares, uma maior incidência de variantes altas na fala dos indivíduos mais velhos, o que indica que o alteamento, que vem se mantendo estável ao longo do tempo, parece apresentar sinais de regressão, como já apontara Bisol (1981), no que respeita à fala do Rio Grande do Sul. Por outro lado, fatores vinculados ao sexo e ao nível de escolaridade podem ser relevantes a depender das comunidades de fala consideradas. (ROCHA; BRANDÃO, 2015, p. 360; 362)

Tendo em vista as observações contidas em (b), acima, apresentam, num mapa, as localidades em que /e o/ se concretizam como médias abertas, que, para as autoras, constitui o traço divergente da fala dessas áreas, uma vez que nelas predominam as variantes fechadas (c.f. Figura 5.1).

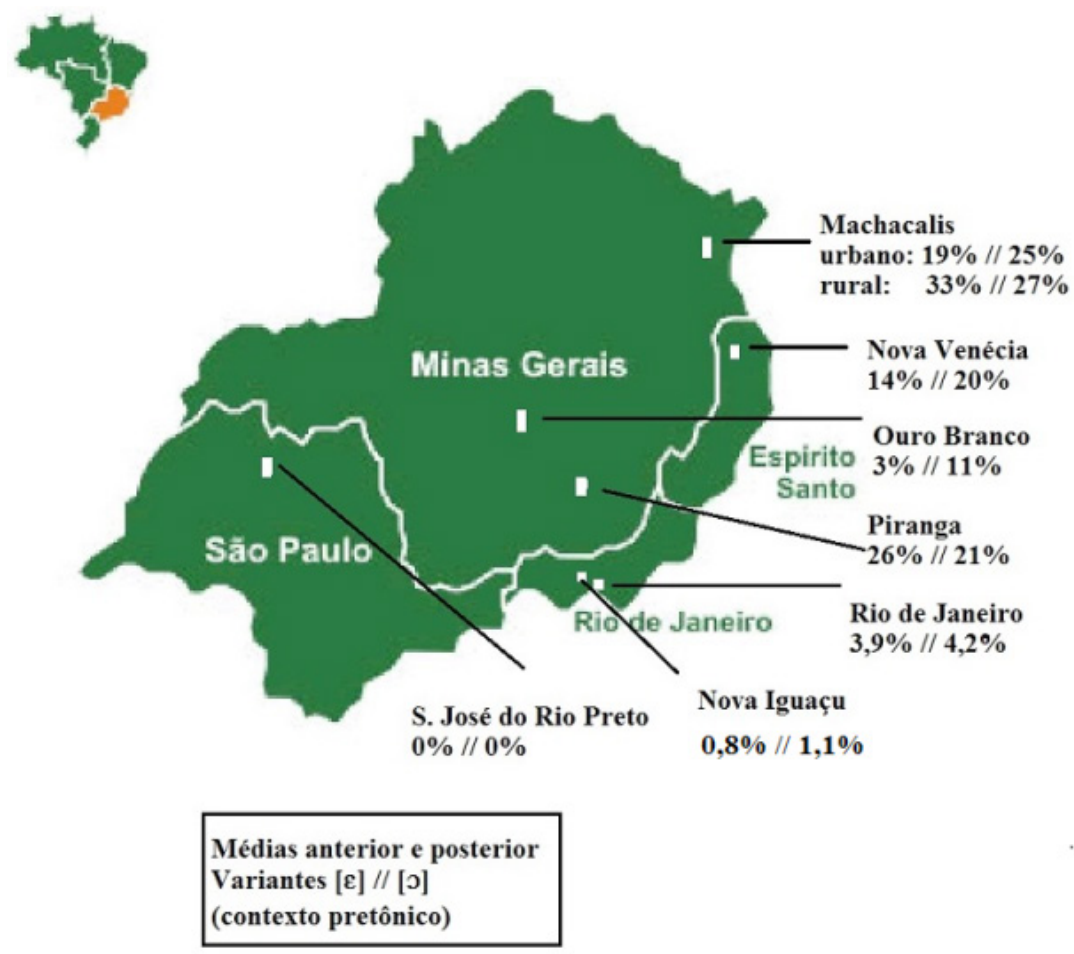

Figura 5.1 Incidência das variantes [ $\varepsilon$ ] em falares da Região Sudeste, com base em Rocha; Brandão $(2015$, p. 361). Fonte: adaptada de <http://www.brasilescola.com/brasil>. 


\subsubsection{Falares do Centro-Oeste}

Para caracterizar a Região Centro-Oeste, selecionaram-se os estudos de Borttoni et al (1992) e de Graebin (2008), que tratam da questão também do ponto de vista difusionista, esta última, inclusive, com base na Teoria dos Exemplares, de Bybee (2002).

Bortoni et al (1992) apoiaram-se em dados fornecidos por falantes de classe média e média baixa representativos de Brasília, cujo dialeto é por elas classificado como "emergente", por lá não existir um "substrato predominante" em virtude do recente processo de formação da cidade que determinou uma situação de intenso contato entre dialetos regionais e sociais (p. 11). Vale lembrar que, no $\mathrm{ALiB}$, a capital federal não constitui um dos pontos de inquérito exatamente por essas características.

Graebin (2008) focaliza a fala de Formosa, Goiás, em que predominam as médias fechadas e o abaixamento é da ordem de 13,2\%, índice bem menor que o registrado por Silva (1991) em Salvador - 59\% - e Soares (2004) - 50,5\% -, em Jeremoabo, não se aplicando, portanto, a esse falar as três regras propostas pela primeira dessas autoras para caracterizar o que ocorre nas variedades baianas. Nesse sentido, a fala de Formosa (em que não se encontram casos categóricos de [ $\varepsilon$ o]), incluída por Nascentes (1953) na área do Subfalar Baiano se afastaria do que se verifica nessa variedade.

Fatores de natureza social, no entanto, foram relevantes, como evidenciou o controle da variável classe econômica. Embora, como se esperaria, as variantes de prestígio [e o] tenham sido favorecidas pela classe alta, $[\varepsilon$ o $]$ apresentaram maior ocorrência entre os indivíduos de classe média e não entre os da classe baixa, em que o índice foi neutro. Segundo a autora, a classe média em Formosa,

tem esboçado um movimento oposto ao observado em outros estudos: não prefere a variante menos marcada [e o] nem faz uso da hipercorreção. Ao invés disso seleciona a variante estigmatizada [ $\varepsilon$ o]. É possível que essa seja uma maneira de a classe média formosense demonstrar sua atitude positiva em relação à língua e à cultura locais e, ao mesmo tempo, uma maneira de rejeitar as influências linguísticas provenientes de Brasília, que chegam, muito provavelmente, via classe alta (p. 193).

\subsubsection{Falares do Nordeste e do Norte}

Dos estudos sobre os falares nordestinos, são aqui brevemente comentados os de Silva (1991, 2008) e o de Nascimento Silva (2009).

Silva (1991, 2008), trata das médias pretônicas, respectivamente, nas falas de Salvador e de Recife, indicando, para a primeira delas, a existência de três re- 
gras vinculadas ao timbre - regra categórica de timbre, regra variável de elevação e regra variável de timbre, esta última condicionada por fatores de ordem social. Dentre elas, as duas primeiras também atuam na fala de Recife. Os índices por ela obtidos na fala de Salvador encontram-se na Figura 5.2 (a) e (b).

(a)

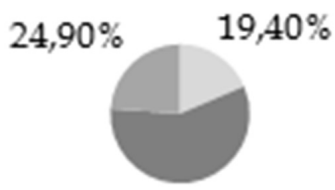

\section{$[\mathrm{e}] \sqcap[\mathrm{E}] \sqcap[\mathrm{i}] \quad 60,30 \%$}

(b)

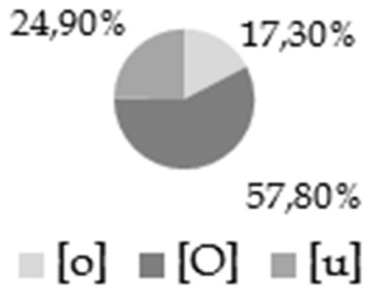

Figura 5.2 Gráficos organizados com base nos índices de concretização das variantes de /e/ e /o/ pretônicos obtidos por Silva (1991) na análise sobre a fala culta de Salvador'.

Fonte: Brandão, 2015.

Já Nascimento Silva demonstra que, no falar teresinense, operam, no contexto pretônico, três regras de harmonização - com média aberta, com média fechada e com vogal alta -, dependentes da altura da vogal subsequente. A par desse quadro, constatou a existência do que denominou de variação tripartida, que ocorre no mesmo vocábulo em ambiente de vogal alta subsequente.

$\mathrm{Na}$ Figura 5.3 (a) e (b), a seguir, pode-se ter uma visão mais clara do que ocorre nesse falar.

(a)

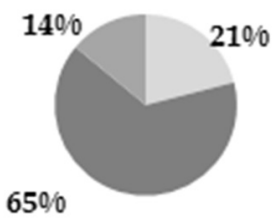

$\square[\mathrm{e}]=[\mathrm{E}]=[\mathrm{i}]$ (b)

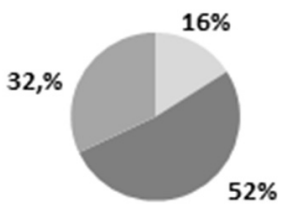

$[\mathrm{o}] \backsim[\mathrm{O}] \backsim[\mathrm{u}]$

Figura 5.3 Gráficos organizados com base nos índices de concretização das variantes de /e/ e /o/ obtidos por Nascimento Silva (2009) na análise sobre a fala de Teresina.

Fonte: Brandão, 2015

$4 \quad[\mathrm{E}]$ e $[\mathrm{O}]$ representam, respectivamente, $[\varepsilon]$ e $[0]$. 
Como se pode verificar, pelas Figuras 5.2 e 5.3, os índices referentes às vogais médias abertas em Salvador e em Teresina são semelhantes, o que permitiria afirmar que as duas localidades fazem parte da mesma área linguística, como se supõe também acontecer com Natal-RN, pelos dados expostos por Maia (1986). Bisol (2011) com base nos resultados de Nascimento Silva e nos de Razky; Santos (2009) sobre a fala paraense, sugere que, nesses falares, estaria atuando um processo de harmonização gradiente.

Sobre a Região Norte, entre outros, há o trabalho de Freitas (2003), que mostrou que em Bragança-PA predominam as variantes [e o], havendo uma pequena oscilação entre as médias aberta e fechada tanto na série anterior quanto na posterior (diferença, respectivamente, de três e quatro pontos percentuais), como fica patente na Tabela 5.1.

Tabela 5.1 Distribuição das variantes de /e o/ em Bragança-PA

\begin{tabular}{cccccc}
\hline$[0]$ & {$[0]$} & {$[\mathrm{u}]$} & {$[\mathrm{e}]$} & {$[\varepsilon]$} & {$[\mathrm{i}]$} \\
$39 \%$ & $36 \%$ & $26 \%$ & $45 \%$ & $41 \%$ & $14 \%$ \\
\hline
\end{tabular}

Fonte: FREITAS, 2003.

A autora, que se baseou numa amostra de 4.087 dados tratados por meio de análise ternária, mostra que há forte tendência à harmonização vocálica: variantes baixas, médias e altas são favorecidas pelas respectivas homorgânicas. No que tange às variáveis sociais consideradas - sexo, faixa etária (três), níveis de renda (dois) e de escolaridade (três) -, esta última foi a mais saliente, uma vez que "maior escolaridade propiciou a realização das variantes médias, ao passo que menos escolaridade propiciou a realização das variantes altas" (p. 124).

Razky; Santos (2009), há pouco mencionados, tratam apenas da vogal/e/ em seis municípios do Pará. No cômputo geral, obtiveram os índices de 33\% para [ع], $41 \%$ para [e] e [26\%] para [i], que iriam ao encontro, no que toca à variante [e], dos obtidos por Freitas (2003) em Bragança - 45\% (c.f. Tabela 5.1) , por Araújo (2007), em Cametá - 39\% - por Campos (2008), em Mocajuba: 49\%. Comparando seus resultados aos de outros estudos realizados no Estado, sugerem que eles permitiriam "reclassificar a pauta pré-tônica no Norte/Nordeste e incluir uma amazônica caracterizada pela variante média alta, tendo-se o Pará como um de seus representantes" (p. 19).

Os autores lembram, no entanto, que os pesos relativos obtidos na análise variacionista (p. 36) demonstram diferentes realidades (c.f. Figura 5.4): há três localidades em que predomina a média alta (Belém, Soure e Almerim) e dois em que a média baixa é mais produtiva (Altamira e Jacarecanga). Marabá se diferenciaria 
das referidas localidades pelo fato de ali não só as duas variantes médias estarem em concorrência, mas também a variante alta ser a preferencial.

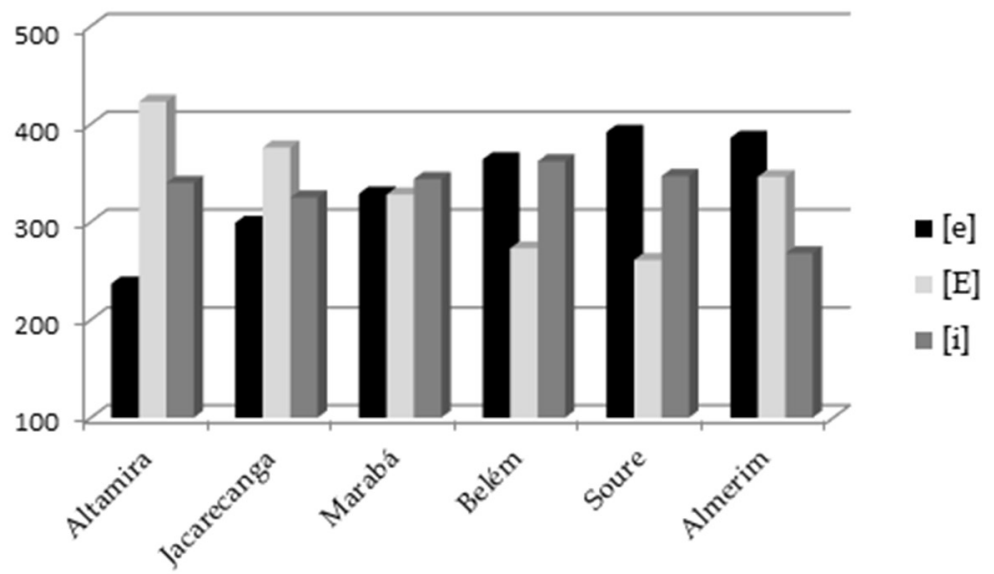

Figura 5.4 Gráfico organizado com base nos pesos relativos obtidos por Razky; Santos $(2009$, p. 36) na análise ternária sobre a variação de /e/ pretônico em seis municípios do Estado do Pará.

Fonte: Brandão, 2015

Deve-se mencionar que os resultados apresentados nesses estudos vão ao encontro, no que se relaciona ao Pará, dos apresentados por Brandão; Cruz (2005), com base nos dados do Atlas Linguístico do Amazonas-ALAM (CRUZ, 2004) e do Atlas Linguístico Sonoro do Pará-ALiSPA (RAZKY, 2004), conforme pode ser observado na Figura 5.5 (a) e (b).

(a)

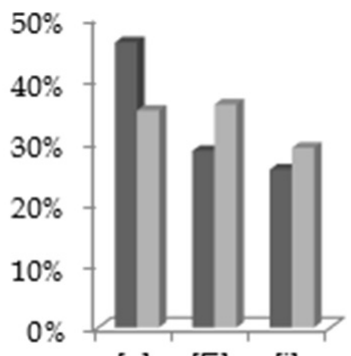

[e] [E] [i]

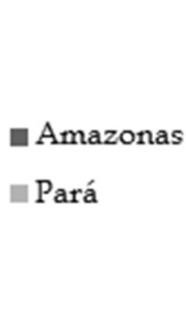

Figura 5.5 Distribuição das variantes de /e/ e /o/ pretônicos em dados do ALAM e do ALiSPA, com base em Brandão; Cruz $(2005$, p.305).

Fonte: Brandão (2015). 


\subsection{OS RÓTICOS}

Os róticos são conhecidos por sua considerável variabilidade entre as línguas do mundo. Em português, do ponto de vista fonológico, a identificação de uma chamada vibrante simples, como em 'caro', em oposição a uma chamada vibrante múltipla, como em 'carro' - apenas no contexto intervocálico - não oferece dificuldade. Do ponto de vista fonético, no entanto, a identificação do tipo de realização da chamada vibrante forte já não é tão simples, dada a sua variabilidade, principalmente, se forem comparados falares de diferentes regiões:

i) vibrante múltipla anterior ápico-alveolar sonora;

ii) vibrante múltipla posterior sonora (uvular, de preferência);

iii) fricativa velar surda (diante de consoante sonora pode realizar-se como sonora);

iv) fricativa glotal (aspiração); e

v) zero fonético, em posição de coda silábica externa.

Pode-se admitir que o processo de posteriorização do $R$ constitua um universal linguístico e que, em português, remonte a fins do século XIX (VIANA, 1883. p. 20; 1902, p. 19):

Ele se pronuncia um pouco mais para trás que o $\underline{\mathrm{r}}$ simples e é geralmente lingual. Podemos encontrar individualmente $\underline{\mathbf{r}}$ vibrantes uvulares, mesmo entre aqueles que pronunciam o $\underline{r}$ simples como lingual [...]. Algumas vezes pronuncio o $\underline{r}$ inicial como uma fricativa sonora, uma espécie de $\underline{\operatorname{rz}}$ [...]. Encontrei raramente esta particularidade na pronúncia de outras pessoas portuguesas. Este $\underline{\mathbf{r}}$ fricativo sonoro é entretanto bastante frequente na pronúncia de brasileiros [...]; não saberia dizer, todavia, até que ponto esta pronúncia é individual ou dialetal: eu a notei entre naturais de Pernambuco e de São Paulo.

A pronúncia uvular $\underline{\operatorname{rr}}[\ldots]$ difundiu-se cada vez mais nas cidades. Entretanto, considera-se ainda viciosa, sendo preferível sempre o $\underline{\mathrm{rr}}$ apical ao grasseyment do $\underline{\mathrm{R}}$.

A afirmação de Houaiss (1970, p. 35) de que "o /R/ carioca ocorre como [...] uvular surdo e sonoro; velar e alveolar, este último múltiplo ou simples...” foi refutada por Nascentes, ao afirmar que para O Linguajar Carioca (NASCENTES, 1953 ) só observou os analfabetos e que nunca ouviu o $/ R /$ uvular surdo ou sonoro na área carioca.

Em trabalho sobre a pronúncia radiofônica do Rio de Janeiro, Soares (1977, p. 14), a partir de entrevistas feitas com locutores dessa cidade, conclui que “... o /r/, vibrante múltiplo ápico-alveolar, é considerado por muitos pronúncia artificial no Rio, mas é ainda o que a maioria realiza". 


\subsubsection{Vibrante versus fricativa}

Callou (1987), ao analisar a fala culta da cidade do Rio de Janeiro, conclui que a variante que predomina, na década de 70, é a fricativa velar, exceto quando em posição de coda silábica final, em que ocorre preferencialmente o apagamento ou a aspiração do $R$. Outra conclusão a que chega é a de que a mudança da norma de pronúncia estaria mais avançada entre as mulheres, em todos os contextos, embora mais flagrante em posição inicial, como se pode verificar na Figura 5.6, em contraste nítido com os falantes do gênero masculino (p.r. .79 versus .21, respectivamente).

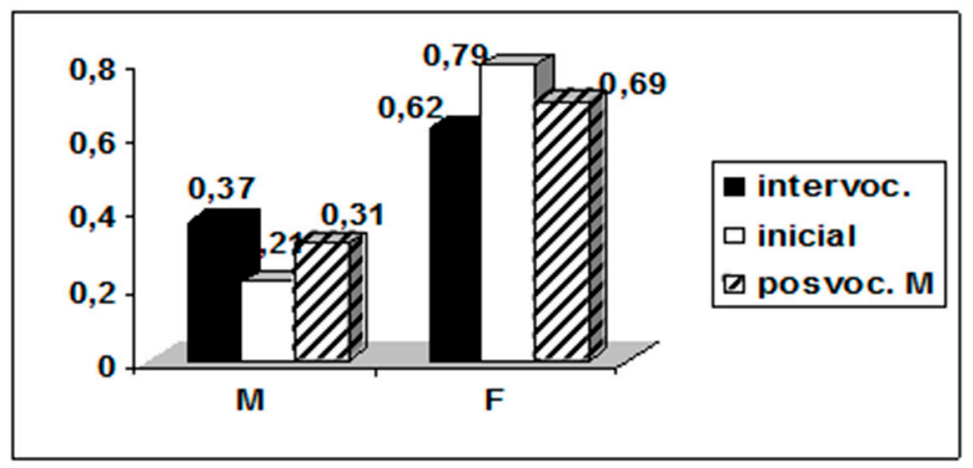

Figura 5.6 Taxa de ocorrência da variante fricativa por gênero e contexto.

Outros condicionamentos assinalados pela autora são a área de residência do falante e a faixa etária, como se pode verificar na Figura 5.7. A realização fricativa predomina na área suburbana - aparentemente, mais inovadora.

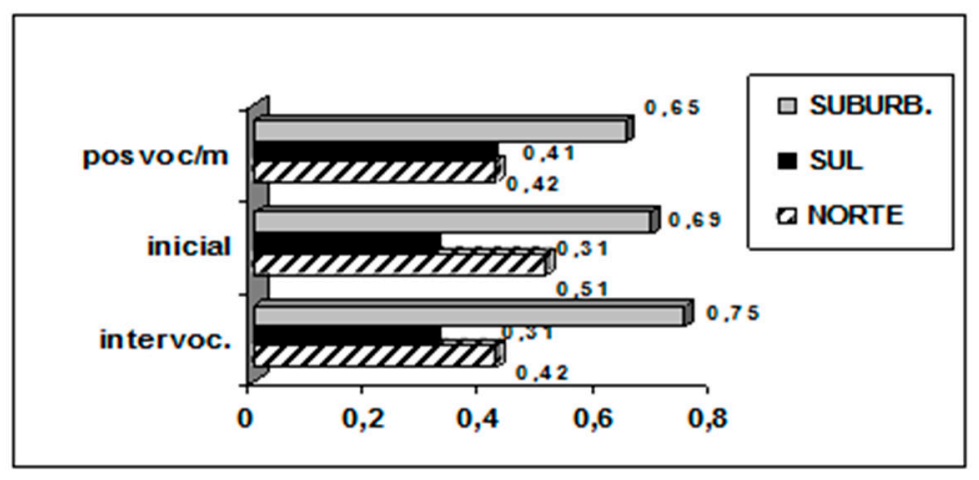

Figura 5.7 Taxa de ocorrência da fricativa velar (PR) por área de residência e contexto.

A distribuição por faixa etária indica uma curva de mudança em curso, em tempo aparente, com ápice de uso da variante mais inovadora na faixa mais jo- 
vem e muito semelhante na faixa acima de 51 anos. Em posição intervocálica, a curva é mais acentuada por haver uma queda da primeira para a segunda faixa etária, o que não ocorre nas demais posições.

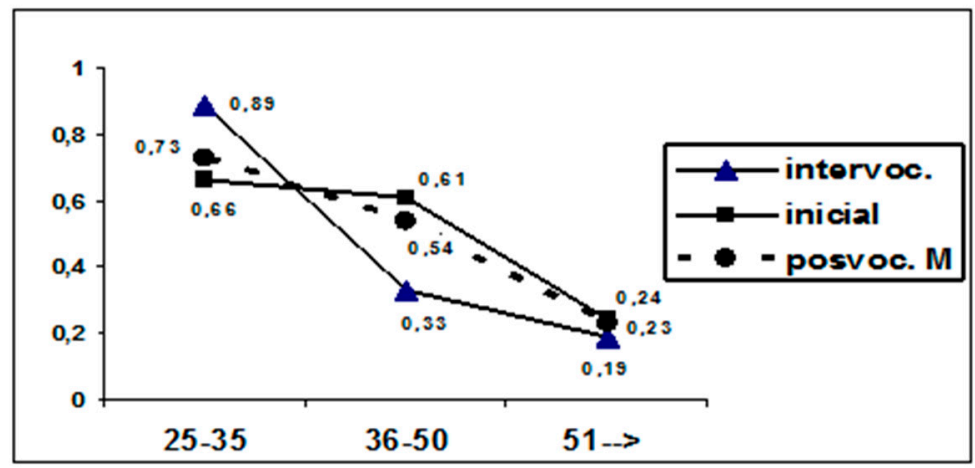

Figura 5.8 Taxa de ocorrência da fricativa velar (Peso Relativo) por faixa etária e contexto.

Callou; Leite; Moraes (2002), analisando dados da década de 1990, verificaram ser a fricativa glotal e não a fricativa velar a variante que predomina hoje em muitos dialetos, em todos os contextos. Na década de 1970, esse uso era ainda incipiente em onset. O processo poderia ser explicado como um enfraquecimento, não exclusivo da posição pós-vocálica. Atualmente, essa simplificação é formalizada como um processo de debucalização, que cancela os traços da cavidade oral (ABAURRE; SÂNDALO, 2003).

Estudos sociolinguísticos recentes já comprovaram também que a variação regional não pode ser deixada de lado, ainda que seja para confirmar que determinados fenômenos se aplicam a vários pontos do país de modo semelhante ou de modo distinto, pelo menos, em termos percentuais. A Figura 5.9 apresenta a taxa de ocorrência de posteriorização/fricativização na fala culta de cinco cidades, com base em amostras da década de 1970 do século XX, e deixa clara a oposição existente entre as cidades de Porto Alegre e São Paulo e as do Rio de Janeiro, Salvador e Recife.

Em trabalho de 1996, Callou et al. analisam a realização do $R$ em posição de travamento silábico nos cinco centros urbanos do Projeto NURC, usando apenas as amostras da década de 1970. O grupo de fatores posição internalexterna no vocábulo foi selecionado como o mais significativo. Assim, o comportamento do $R$ em final de vocábulo deve ser analisado separadamente, uma vez que a posição final (externa) constitui o ambiente em que o apagamento se dá mais frequentemente, como se pode ver nas Figuras 5.10 e 5.11, que levam em conta apenas o dialeto carioca, em cada década, com distribuição similar. 


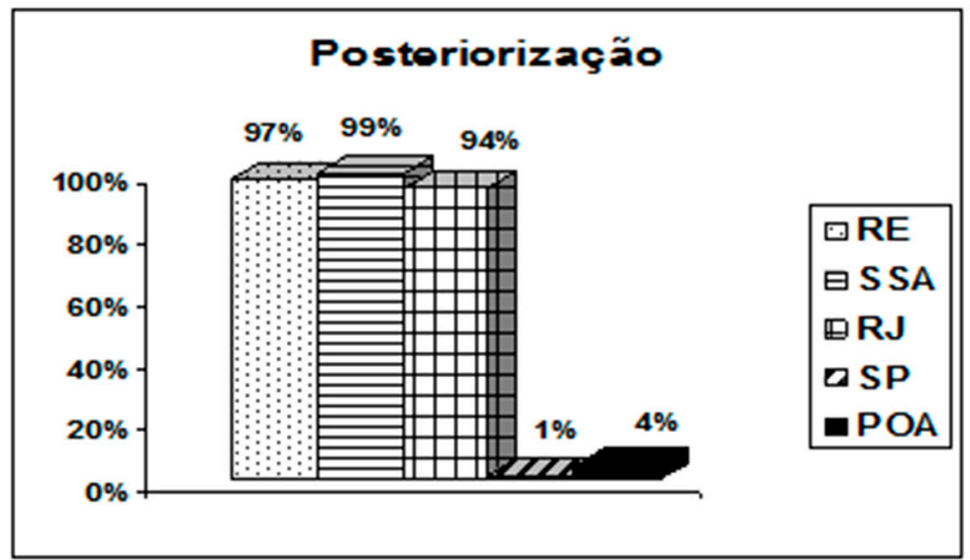

Figura 5.9 Posteriorização do /R.

\section{Década de 70}

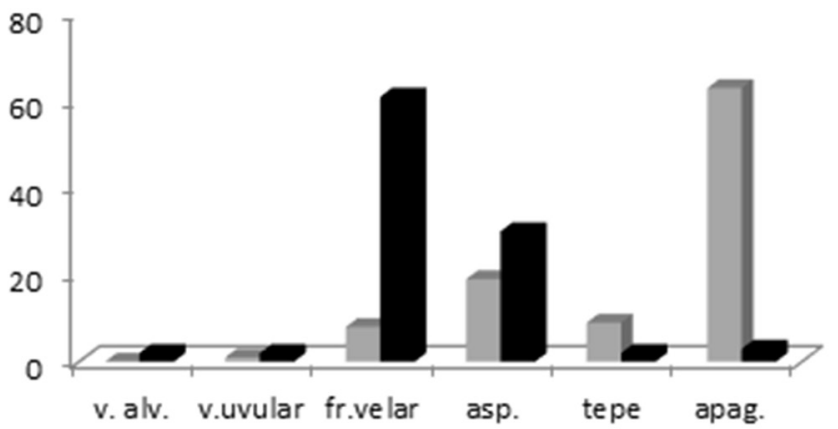

Posição

Externa

Posição Interna

Figura 5.10 Realização do $R$ em posição interna e externa no dialeto carioca, na década de 1970.

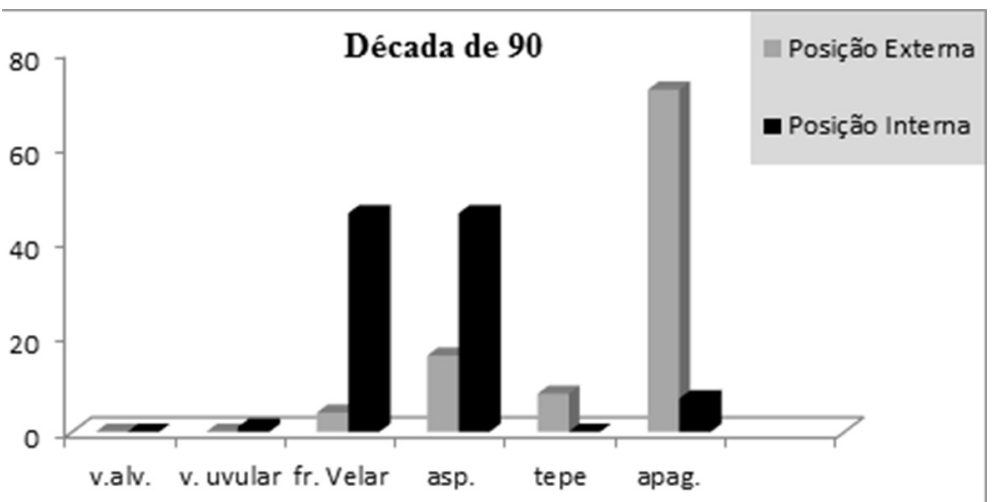

Figura 5.11 Realização do $R$ em posição interna e externa no dialeto carioca na década de 1990. 
Estudos recentes (MONARETTO, 2002), com base em dados das décadas de 1980 e 1990 da região Sul já indicam um decréscimo da vibrante alveolar e um crescimento da fricativa velar, notadamente, em onset. Na posição de coda, o tepe predomina (60\%), seguido do apagamento do segmento que chega a $25 \%$.

Embora não seja sempre possível estabelecer linhas demarcadoras de fenômenos linguísticos que singularizariam os dialetos, no que diz respeito à realização do rótico, em coda silábica interna, como fricativa posterior, é possível opor nitidamente uma região mais ao sul - São Paulo e Porto Alegre (SP e POA) - a uma região mais ao norte, abrangendo Rio de Janeiro (RJ), Salvador (SSA) e Recife (RE) - cf. Figura 5.12 - , tomando por base os dados do Nurc.

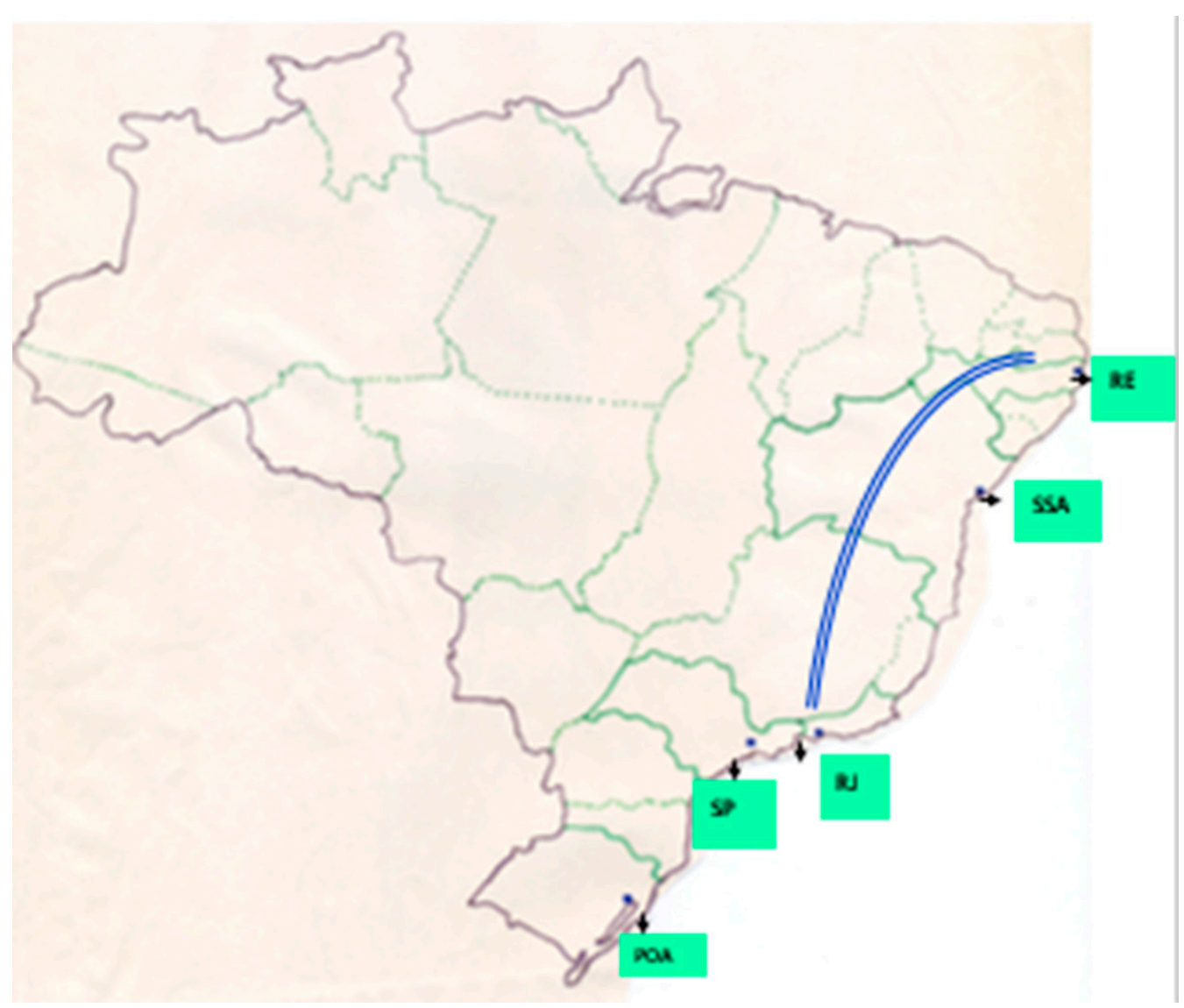

Figura 5.12 Distribuição das cidades objeto de estudo do Nurc.

\subsection{2 $O$ processo de apagamento}

Em final de vocábulo, pode-se dizer que o apagamento do $R$ é um fenômeno antigo no português do Brasil. O processo, em seu início considerado uma carac- 
terística dos falares incultos, era utilizado, no século XVI, nas peças de Gil Vicente, para singularizar o linguajar dos escravos. O fenômeno expandiu-se paulatinamente, é hoje comum na fala dos vários estratos sociais e corresponde ao estágio final de um processo de enfraquecimento que leva à simplificação da estrutura silábica no Português do Brasil ( $\mathrm{R} \rightarrow \mathrm{h} \rightarrow \varnothing$ e, consequentemente, $\mathrm{CVC} \rightarrow \mathrm{CV}$ ).

A perda do $R$ final tem sido avaliada sob ângulos diversos: um que a considera uma pronúncia estereotipada, um demarcador social, com indícios de recuperação, inclusive em hipercorreções - café - $r$ - amargo - (HOUAISS, 1970); outro, que prediz sua completa perda em dialetos não-padrão (D'ARC, 1992).

Confrontando trabalhos já realizados, com os corpora do N, Callou; Leite; Moraes (2002), e com os corpora do PEUL, (MOLLICA; FERNANDEZ, 2003), pode-se verificar que o cancelamento do $\mathrm{R}$, em final de palavra, tanto em verbos como em não verbos, é um fenômeno marcante no português do Brasil, notadamente, nos infinitivos dos verbos, contexto em que a regra se encontra em estágio mais avançado. A julgar pelas análises já empreendidas, a queda do $R$ transpôs qualquer estratificação social e se estendeu a todos os indivíduos falantes do português brasileiro, principalmente, em certas regiões. O processo obedece aos mesmos condicionamentos e se mantém relativamente estável no decorrer de 20 anos. A utilização das amostras citadas teve por finalidade demonstrar que a única diferença entre os resultados nos dois tipos de amostra, que retratam escolaridade diferenciada, reside no aspecto quantitativo e não na qualidade da produção. Do corpus NURC foram analisados 2723 casos, na década de 1970, 506, na década de 1990, da amostra recontato, e 817 da nova amostra, na década de 90. Do corpus Peul, foram analisados 1359 dados, da década de 1980 , e 900 da nova amostra, no ano 2000.

Os resultados até agora mostram que o cancelamento da é sensível a consoante (i) fatores estruturais, o mais relevante deles, classe morfológica, o que determinou a análise separada dos dados - e (ii) a sociais, tais como grau de escolaridade e faixa etária, encontrando-se em estágio mais avançado na fala de informantes que não possuem curso universitário e apresentando distribuição de uso distinta ao se cruzarem os grupos faixa etária e gênero. Conforme se vê na Figura 5.13, a grande oposição reside, mais uma vez, na classe morfológica: nos verbos, o percentual de cancelamento está sempre acima de $60 \%$ e nas demais categorias abaixo de $40 \%$, os valores mais altos encontrando-se em falantes de menor escolarização. Observe-se que somente entre falantes com grau universitário há um aumento da frequência de apagamento, da década de 1970 para 1990, o que é um forte indicativo de se tratar, nos termos de Labov (1994), de uma mudança "de baixo para cima". 


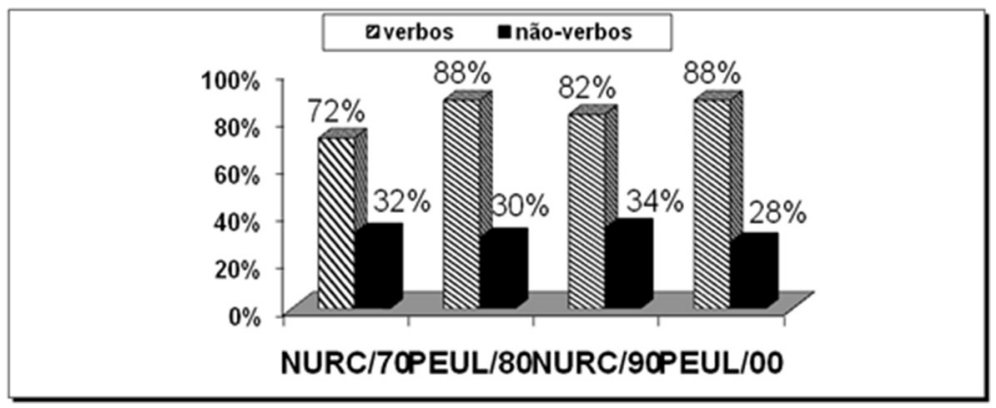

Figura 5.13 Apagamento do R em verbos e não verbos no Nurc e no Peul.

Observando-se as variáveis sociais, faixa etária e gênero, na amostra NURC/ RJ, para um estudo de tendência (comportamento da comunidade/indivíduos distintos, em dois recortes temporais), verifica-se uma nítida oposição no comportamento de homens e mulheres. As curvas de distribuição indicam, para os homens, uma variação estável, em ambos os períodos. Os falantes mais jovens não modificam o seu comportamento dos anos 1970 para os anos 1990, mas o segundo e terceiro grupos, adultos e idosos, apresentam comportamentos opostos: nos anos 1970, o peso relativo decresce da terceira para a segunda faixa etária e aumenta da segunda para a primeira; nos anos 90, há um aumento da terceira para a segunda e uma diminuição da segunda para a primeira. Uma provável explicação para esse aumento na segunda faixa - que coincide, no Brasil, com a senioridade na vida profissional - é a de o apagamento do $R$ não ser mais uma pronúncia estigmatizada, ao menos em verbos, correspondendo a uma nova norma introduzida na comunidade.

No Peul, é significativa a mudança de 1980 para 2000, mas apenas para os falantes mais idosos, acima de 50 anos. Comparando os percentuais e input geral de aplicação da regra de apagamento, em todos os corpora, sem levar em conta as variáveis gênero e faixa etária, no estudo de tendência, verifica-se que a comunidade (c.f. Tabela 5.2) se mantém estável, com aumentos percentuais progressivos, embora com distribuição diferenciada por faixa etária.

Tabela 5.2 Comportamento da comunidade nos dois períodos

\begin{tabular}{ccccc}
\hline & \multicolumn{2}{c}{ NURC } & \multicolumn{2}{c}{ Peul } \\
Apagamento do $\boldsymbol{R}$ em verbos & $\%$ & P.R & $\%$ & P.R \\
\hline Década de $1970 / 1980$ & $73 \%$ & .70 & $91 \%$ & .91 \\
$1990 / 2000$ & $82 \%$ & .82 & $92 \%$ & .92 \\
\hline
\end{tabular}

Assim, para o entendimento da atuação da regra de apagamento do R, é necessário distinguir a classe morfológica do vocábulo, além da posição que o seg- 
mento ocupa: interna (final de sílaba) ou externa (final de vocábulo). Há indícios, pois, de que os condicionamentos são tanto fonológicos, quanto morfológicos e sociais. Isso contradiz a hipótese neogramática mais radical, para a qual prevaleceriam apenas fatores fonético-fonológicos na implementação da mudança.

Os dados aqui apresentados mostram a complexidade do estudo da mudança linguística. No caso em pauta, essa complexidade fica bastante evidente. Em primeiro lugar, há que diferençar falantes do sexo masculino de falantes do sexo feminino - uma comunidade cindida, portanto - e, em segundo, distinguir entre verbos e não verbos. Por fim, observe-se que o apagamento do $\boldsymbol{R}$ final tem sido considerado um caso de mudança de baixo para cima que, ao que tudo indica, já atingiu seu limite, e é hoje uma variação estável, sem marca de classe social. A avaliação da situação geral, com base nos estudos em tempo aparente e em tempo real indicam antes um equilíbrio que a previsão de um completo apagamento.
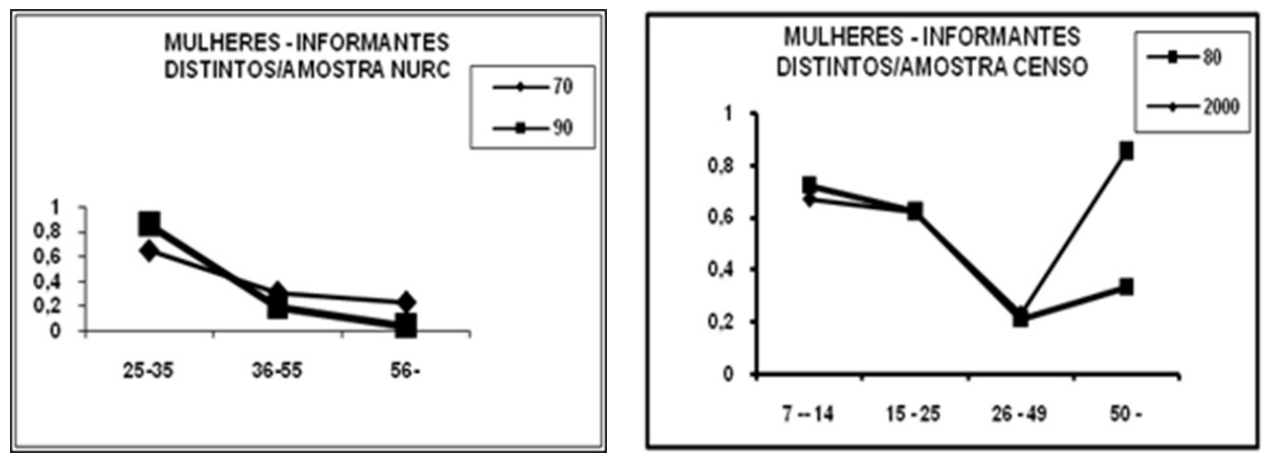

Figura 5.14 Apagamento do $R$ em tempo real de curta duração no Nurc (fala padrão) e no Peul (fala não padrão), por faixa etária, em mulheres.

Comparando todas as amostras, observa-se que, no $\mathrm{N}$, não há mudança, em falantes femininos, da década de 1970 para a década de 1990, a não ser um ligeiro aumento entre os jovens de 25 a 35 anos. As curvas de distribuição indicam mudança em progresso nos dois casos, expressa no gráfico pela quase superposição das linhas. No Peul, é significativa a mudança de 1980 para 2000, mas apenas para os falantes mais idosos, acima de 50 anos. Entre os homens jovens, há uma semelhança entre NURC e Peul, com a diferença de ter havido diminuição do cancelamento do R em 2000 em falantes abaixo de 15 anos no sentido da aquisição e não da perda, portanto) e ligeiro acréscimo entre os de 24 a 49, que corresponde em parte à faixa etária do NURC de 36 a 55, que apresenta comportamento semelhante. 

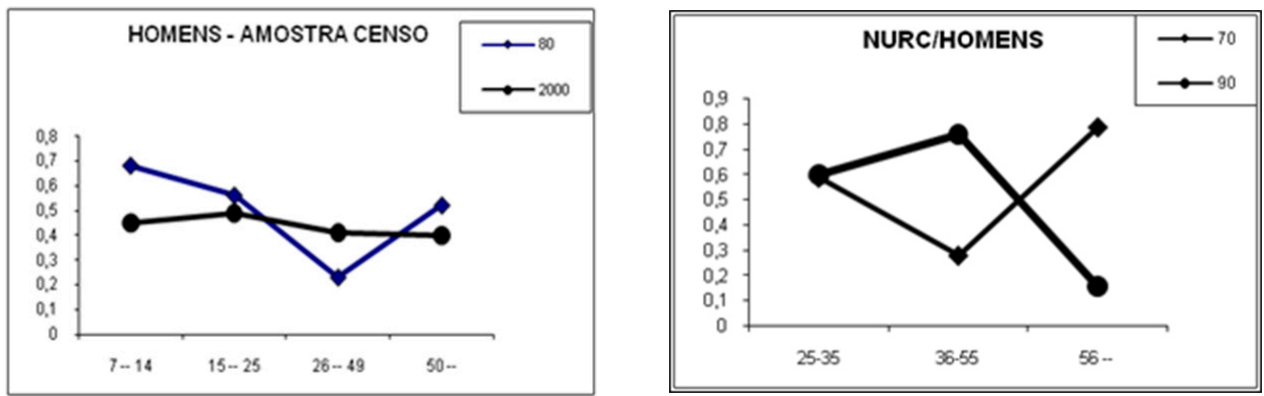

Figura 5.15 Apagamento do $R$ nos dois corpora, em duas décadas, nas duas amostras, por faixa etária, nos homens.

Poderia indagar-se por que o rótico se enfraquece a ponto de ser cancelado, quando em posição de coda e não quando em onset. Sem dúvida, o apagamento torna a sílaba aberta, modificando a estrutura silábica e alcançando o padrão ideal CV. Em onset, o apagamento conduz ao padrão V e à possibilidade de encadeamento de várias vogais, o que não é, de um modo geral, desejável nas línguas. Na verdade, todas as consoantes que travam sílaba $-\boldsymbol{s}, \boldsymbol{r}, \boldsymbol{l}$ - podem ser canceladas no português do Brasil. Uma resposta pode ser encontrada no Princípio de sequenciamento da sonoridade, que exige o aumento da sonoridade dos onsets silábicos na direção do núcleo e a sua diminuição a partir do núcleo para a coda. Esse princípio, que se aplica à constituição dos grupos consonantais reformula em termos de sonoridade o que os fonetistas já diziam há muito tempo: existe uma tendência a aumentar o desequilíbrio ou a assimetria que constitui uma lei fundamental da sílaba, reforço da explosão e debilitação da implosão silábica, já referida anteriormente. Nessa perspectiva, o enfraquecimento do $\boldsymbol{R}$ pode ser visto como uma tendência a tornar maior a distância entre a sonoridade do núcleo e a da coda.

Em relação ao apagamento em sílaba final de vocábulo, observam-se comportamentos diferenciados por classe morfológica e por cidade, o percentual geral de apagamento não sendo o mesmo nas cinco cidades, como se pode verificar na Figura 5.16, embora a diferenciação fique menos nítida se não for considerada a oposição de classe morfológica.

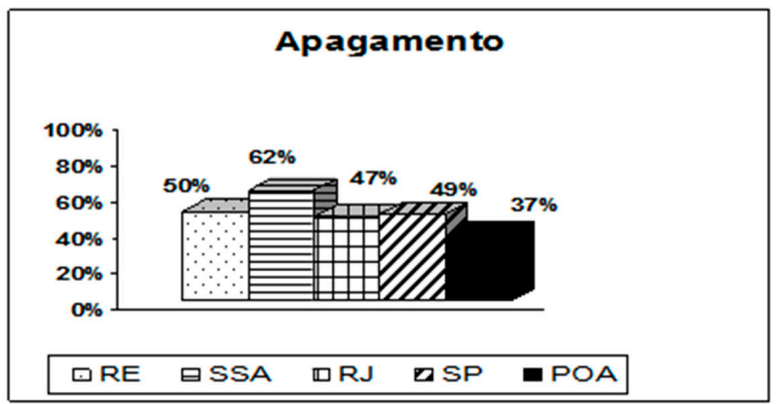

Figura 5.16 Apagamento do $R$ em sílaba final de vocábulo, sem discriminar classe morfológica. 
Levando em conta a classe morfológica, é nítido um comportamento diferenciado, como se pode observar confrontando três capitais (Figura 5.17), com uma tendência à implementação da regra, entre os mais jovens.
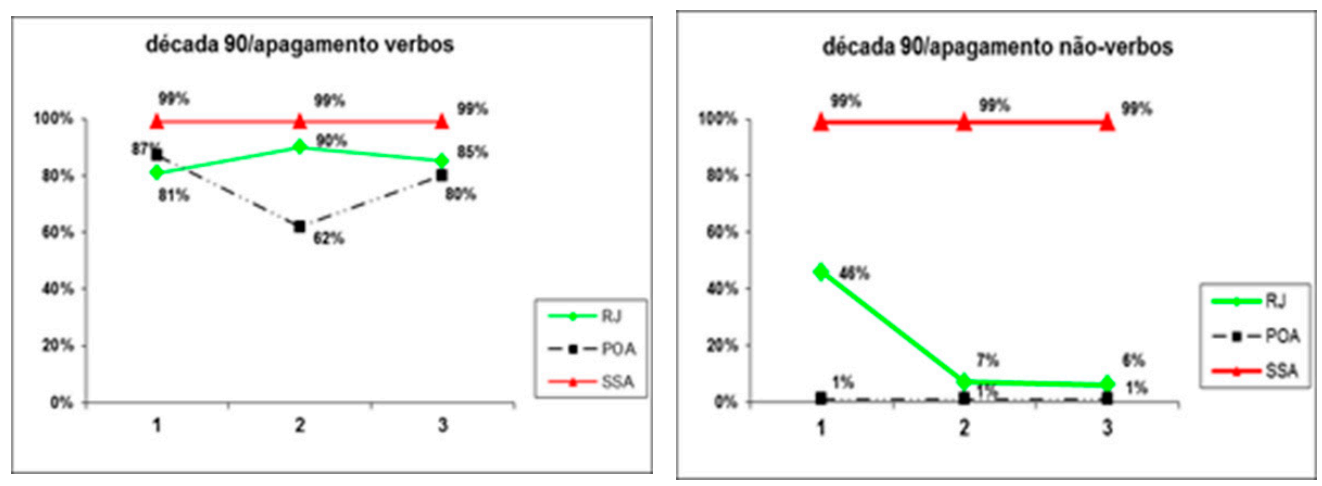

Figura 5.17 Apagamento do Rem posição de coda final, na fala culta do RJ, de SSA e de POA, na década de 1990, por faixa etária, de acordo com classe morfológica.

O apagamento em verbos - anda $(r)$ - é mais frequente do que nos não verbos - poma $(r)$; apesa $(r)$ - em quase todas as cidades, embora com percentuais distintos: em Salvador, a regra já não é sensível à variável classe morfológica e se aplica em todos os casos; em Porto Alegre, a frequência de apagamento não chega a $10 \%$; e, no Rio de Janeiro, o apagamento em não verbos já mostra uma tendência à implementação da regra, entre os falantes mais jovens.

\subsubsection{Análise prosódica}

Em trabalhos recentes (CALLOU; SERRA, 2012; SERRA; CALLOU, 2015), defende-se a hipótese de que a escalaridade do fenômeno de apagamento também se reflita no nível prosódico, a saber, existiria uma relação entre presença versus ausência de $R$, em posição de coda final, e o tipo de fronteira prosódica (NESPOR; VOGEL, 1986):

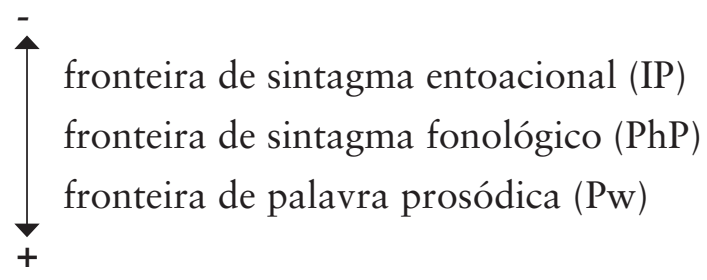

Postula-se, assim, que o domínio do cancelamento, em coda final, vá além da sílaba e que seu locus tenha relação, na verdade, com o tipo de fronteira prosódica: quanto mais alta a fronteira maior a tendência à preservação, o que poderia expli- 
car a diferença de índices de apagamento em fronteiras internas e externas à própria palavra. Em variedades como a de Salvador, em que o apagamento do $R$, em coda final, já era categórico na década de 1990, entre os indivíduos mais jovens, pôde-se comprovar que o tipo de fronteira prosódica já não se mostrou um fator atuante.

Por outro lado, o processo de apagamento do $R$, nas cidades em que ele é variável, mostra-se sensível à variável tipo de fronteira prosódica: é a fronteira prosódica mais baixa, a de palavra prosódica ( $\mathrm{Pw})$, a que mais licencia o apagamento do segmento, ao passo que a fronteira de sintagma fonológico $(\mathrm{PhP})$ e a fronteira mais alta de sintagma entoacional (IP) oferecem maior resistência à queda do $R$. De uma década para a outra, entretanto, mesmo as fronteiras de IP e PhP não mais inibem o apagamento do segmento (Figura 5.18), pelo menos, no Rio de Janeiro.

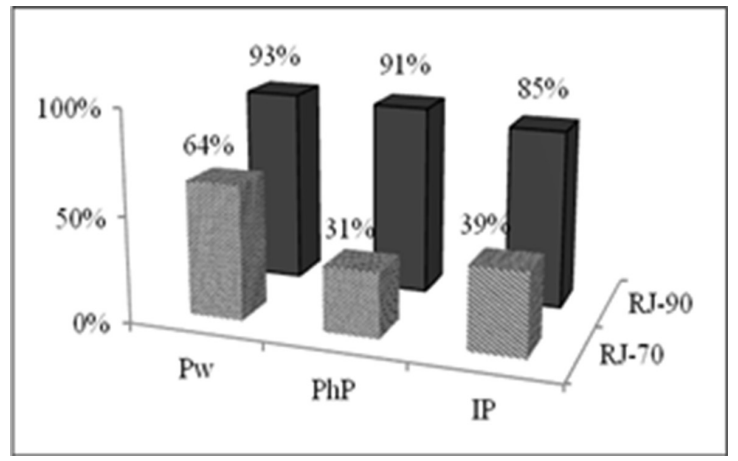

Figura 5.18 Apagamento do $R$ em posição de coda final, na fala culta do RJ, nas duas décadas, de acordo com a fronteira prosódica.

Em Porto Alegre, na década de 1970, o apagamento é mais frequente nas fronteiras de $\mathrm{Pw}$ e de $\mathrm{PhP}$ do que na fronteira de IP (Figura 5.19), relembrando que o processo variável só se aplica aos verbos, na capital gaúcha.

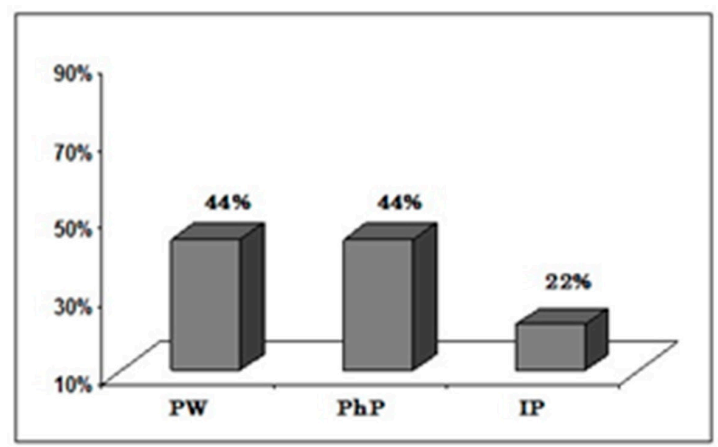

Figura 5.19 Apagamento do $R$ em posição de coda final, na fala culta de POA, na década de 1970, de acordo com a fronteira prosódica. 
Esses resultados vão ao encontro da hipótese sobre o importante papel da fronteira prosódica para a aplicação do processo em pauta, conquanto as cidades do Rio de Janeiro e de Porto Alegre apresentem índices diferenciados de apagamento na fronteira de $\mathrm{PhP}$, os quais, na primeira cidade, se aproximam dos de IP e, na segunda, dos de Pw. De toda forma, em ambas as cidades, é a fronteira mais baixa de palavra prosódica a que favorece o cancelamento do rótico.

Esses resultados encontram respaldo em outras pesquisas já realizadas: os dados de Votre (1978), para a fala adulta, e de Gomes (2006), para a fala de crianças, entre outros, revelam a presença da pausa - marca duracional frequentemente associada à fronteira de IP - como um fator favorecedor da realização da coda, confirmando as afirmações de ser a fronteira de sintagma entoacional a que inibe o processo de apagamento do $R$ final. Em pesquisa recente sobre a aquisição da coda no Português Europeu, Jordão (2009) afirma que a posição final de IP propicia, claramente, tanto as estratégias de reconstrução quanto a realização da coda.

\subsection{CONSIDERAC̣ÕES FINAIS}

a) Apresenta-se, na Figura 5.20, à guisa de conclusão ao item 5.1, uma síntese das observações contidas neste estudo quanto à distribuição diatópica das variantes de /e o/. Para a elaboração do mapa, levaram-se em conta dados que consideraram em conjunto as variantes da média anterior e da posterior na fala das capitais de 25 estados brasileiros, com base em Mota; Cardoso (2015).

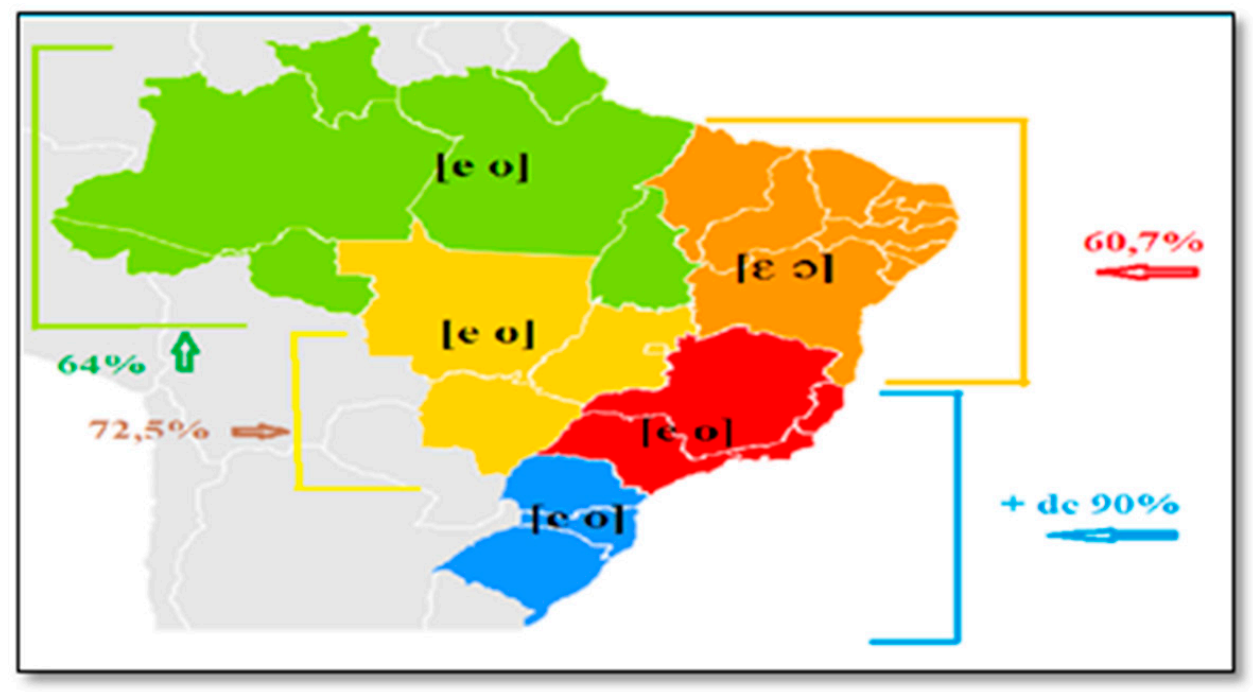

Figura 5.20 Médias anteriores e posteriores consideradas em conjunto na fala de 25 capitais, com base em dados do Projeto ALiB (MOTA; CARDOSO, 2012). 
Deixando-se à parte a complexidade que caracteriza o comportamento das vogais médias pretônicas, por meio do mapa, pode-se verificar que as variantes $[\mathrm{e} o]$ predominam em todas as áreas, exceto no Nordeste, em que $[\varepsilon$ $]$ atingem $60,7 \%$ de ocorrências. Por outro lado (c.f. Figura 5.21), constata-se que a incidência das variantes médio-fechadas, considerando o continuum Sul $\mapsto$ Norte, vai perdendo intensidade, deixando ainda mais evidente a especificidade da área nordestina.

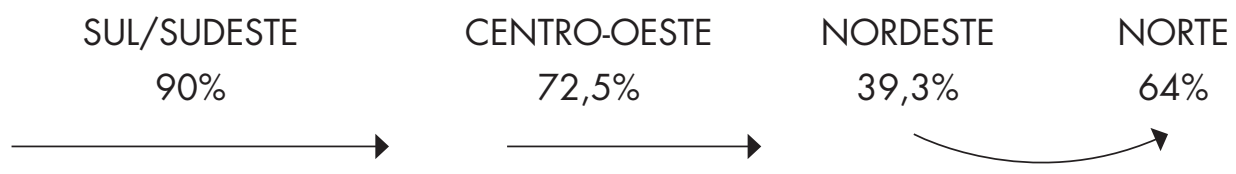

Figura 5.21 Frequência das variantes [e o] em contexto pretônico nas capitais de 25 estados das cinco regiões geo políticas brasileiras.

Fonte: com base em MOTA; CARDOSO, 2012.

b) Pelo que foi exposto no item 5.3, é possível concluir que os róticos estão sujeitos a dois processos - um de posteriorização, paralelo ao de fricativização, e outro de apagamento - que guardam relação entre si, uma vez que os dialetos que mantêm a articulação vibrante anterior correspondem àqueles que preservam mais o segmento.

De um lado, a mudança de ponto de articulação, de anterior para posterior, parece representar uma tendência universal (GRANDA GUTIÉRREZ, 1966; MARTINET, 1969; PAHLSSON, 1972; CALLOU, 1987); de outro, o processo de apagamento, em posição de coda silábica final, (i) teria implicações no processo de simplificação da estrutura silábica, e tem sido explicado pela fonética articulatória, mais recentemente, também pela fonologia prosódica; e (ii) o processo se dá abaixo do nível de consciência do falante, uma mudança 'de baixo para cima', portanto.

Além da distribuição dialetal do fenômeno, interessa ainda aprofundar algumas questões que dizem respeito à possibilidade de cada variante do $\boldsymbol{R}$ representar um passo na escala ordenada de enfraquecimento, que resulta na queda do segmento, ou, ao contrário, corresponder a um único processo, sem etapas intermediárias. Nesse ponto, a hipótese é a de que as variedades do Português do Brasil possam apresentar comportamentos diferenciados no mesmo estágio da mudança. Além disso, é em função da vitalidade do fenômeno, que se apresenta tão diverso em áreas dialetais distintas, que é indispensável dar continuidade à análise do processo, levando em conta as multifaces das realizações do $\boldsymbol{R}$ e seus condicionamentos. 


\section{REFERÊNCIAS}

ABAURRE, M. B.; SANDALO, M. F. Os róticos revisitados. In: HORA, D;

COLLISCHONN, G. (Org.). Teoria Linguística: fonologia e outros temas. João Pessoa:

Editora Universitária, 2003. p. 144-180.

ALMEIDA, L. F. A variação das vogais médias pretônicas na cidade mineira de Machacalis. 2008. 283 f. Dissertação (Mestrado em Linguística) - Universidade Federal de Minas Gerais, 2008.

ARAÚJO, M. As vogais médias pré-tônicas lel e /o/ no português falado no município de Cametá-PA: uma abordagem variacionista. 2007. Dissertação (Mestrado em Letras) Universidade Federal do Pará, Belém, 2007.

BISOL, L. Harmonização vocálica, uma regra variável. 1981. 332 f. Tese (Doutorado em Linguística) - Universidade Federal do Rio de Janeiro, Rio de Janeiro, 1981.

. A neutralização das átonas. Revista DELTA, v. 19, n. 2, p. 267-276, 2003.

. O alçamento da pretônica sem motivação aparente. In: BISOL, L.;

COLliSCHON, G. (Org.). Português do Sul do Brasil: variação fonológica. Porto Alegre: EdiPUCRS, 2009. p.73-92.

BISOL, L. Harmonização gradiente. Diadorim: Revista de Estudos Linguísticos e Literários, n. 8, p. 11-24, 2011.

BORTONI, S. M.; GOMES, C. A.; MALVAR, E. A variação das vogais médias pretônicas no português de Brasília: um fenômeno neogramático ou de difusão lexical? Revista de Estudos linguísticos, Belo Horizonte, v. 1, p. 9-29, jul.-dez. 1992.

BRANDÃO, S. F. Variação e mudança no âmbito do vocalismo. In: MARTINS, M. A.; ABRAÇADO, J.; (Ed.). Panorama sociolinguístico do português do Brasil. São Paulo: Contexto, 2015. p. 11-38

BRANDÃO, S. F.; CRUZ, L. C. Um estudo contrastivo sobre as vogais médias pretônicas em falares do Amazonas e do Pará com base nos dados do ALAM e do ALISPA. In: AGUILERA, V. (Org.). A geolinguística no Brasil: caminhos e perspectivas. Londrina: Editora da Universidade Estadual de Londrina, 2005. p. 299-318.

BRANDÃO, S. F.; ROCHA, F. M. V; SANTOS, E. R. Vogais médias pretônicas em início de vocábulo na fala do Rio de Janeiro. Revista Letras \& Letras, Uberlândia, v. 28, n. 1, p. 244-247, 2012.

BYBEE, J. Word frequency and context of use in the lexical diffusion of phonetically conditioned sound change. Language Variation and Change, n. 14, p. 261-290, 2002. CALLOU, D. Variação e mudança no âmbito do consonantismo. In: MARTINS, M. A.; ABRAÇADO, J. (Ed.). Panorama sociolinguístico do português do Brasil. São Paulo: Contexto, 2015. p. 39-64.

CALLOU, D.; LEITE, Y. As vogais pretônicas no falar carioca. Revista de Estudos Linguísticos e Literários, Salvador, n. 5, p. 151-162, 1986.

CALLOU, D. Variação e distribuição da vibrante na fala culta carioca. Rio de Janeiro: UFRJ/PROED, 1987. 
CALLOU, D.; LEITE, Y.; COUTINHO, L. Elevação e abaixamento das vogais pretônicas no dialeto do Rio de Janeiro. Organon, n. 18, p. 71-78, 1991.

CALLOU, D.; LEITE, Y.; MORAES, J. Variação e diferenciação dialetal: a pronúncia do /r/ no português do Brasil. In: KOCH, I. (Org.). Gramática do português falado. Campinas: Unicamp, 1996. p. 465-493. v. 6.

CALLOU, D.; LEITE, Y.; MORAES, J. Processo(s) de enfraquecimento consonantal no português do Brasil. In: ABAURRE, M. B; RODRIGUES, A. (Org.). Gramática do português falado. Campinas, Unicamp/Fapesp, 2002. p. 537-555. v. 6.

CALLOU, D.; SERRA, C. Variação do rótico e estrutura prosódica. Revista do GELNE, n. 14, p. 41-58, 2012.

CAMARA JR., J. M. Para o estudo da fonêmica portuguesa. Rio de Janeiro: Padrão, 1977.

CAMPOS, B. M. do S. P. Alteamento vocálico em posição pretônica no português falado no Município de Mocajuba-Pará. Dissertação (Mestrado em Letras) - Universidade Federal do Pará, Belém, 2008.

CARMO, M. N. As vogais médias pretônicas dos verbos na fala culta do interior paulista. 2009. 119 f. Dissertação (Mestrado em Linguística) - Universidade Estadual Paulista "Júlio de Mesquista Filho", São Paulo, 2009.

CELIA, G. F. As vogais médias pretônicas na fala culta de Nova Venécia. 2004. 114 f. Dissertação (Mestrado em Linguística) - Universidade Estadual de Campinas, Campinas, 2004.

CRUZ, M. L. C. Atlas Linguístico do Amazonas - ALAM. 2004. Tese. (Doutorado em Letras Vernáculas) - Universidade Federal do Rio de Janeiro, Rio de Janeiro, 2004.

D’ARC, J. Difusão lexical na vibrante final. Dissertação (Mestrado em Linguística) Universidade Federal do Rio de Janeiro, Rio de Janeiro, 1992.

DIAS, M. R. A variação das vogais médias pretônicas no falar dos mineiros de Piranga e Ouro Branco. 2008. 296 f. Dissertação (Mestrado em Estudos Linguísticos) Universidade Federal de Minas Gerais, Belo Horizonte, 2008.

FREITAS, S. As vogais médias pretônicas /e/ e /o/ num falar do Norte do Brasil. In: RASKY, A. (Org.) Estudos geo-sóciolinguísticos no Estado do Pará. Belém: Gráfica e Editora Grafia, 2003.

GOMES, C. Aquisição do tipo silábico CV(r) no português brasileiro. Scripta, Belo Horizonte, v. 9, n. 18, p. 11-28, 2006.

GRAEBIN, G. S. A fala de Formoso/GO: a pronúncia das vogais médias pretônicas. 2008. 243 f. Dissertação (Mestrado em Linguística) - Universidade de Brasília, Brasília, 2008.

GRANDA GUTIÉRREZ, G. La velarización de RR de Puerto Rico. Revista de Filología Española, Madrid, n. 49, p. 181-227, 1966.

HOUAISS, A. Sobre alguns aspectos da recuperação fonética. Anais do Simpósio de Filologia Românica, v. I. Rio de Janeiro, 1970, p. 25-38.

JORDÃO, R. A estrutura prosósica e a emergência de segmentos em coda no PE: um estudo de caso. Dissertação (Mestrado em Linguística Portuguesa) - Universidade de Lisboa, Lisboa, 2009. 
LABOV, W. Principles of linguistic change: internal factors. Cambridge: Blackwell, 1994. LEE, S.; OLIVEIRA, M. A. de. Variação inter-e-intra-dialetal no português brasileiro: um problema para a teoria fonológica. In: HORA, D.; COLLISCHONN, G. (Org.). Teoria linguística, fonologia e outros temas. João Pessoa: Editora Universitária, 2003. MAIA, V. L. M. Vogais pretônicas médias na fala de Natal. Estudos Linguísticos e Literários, Salvador, n. 5, p. 209-225, 1986.

MARTINET, A. $R$, du latin au français d'aujourd'hui. In: Le français sans fard. Paris: Presses Universitaires de France, 1969. p. 132-143

MOLLICA, M. C. de M.; FERNANDEZ, C. de M. Um caso de estabilidade fonológica comprovado em tempo aparente e em tempo real. Revista de Letras, Fortaleza, v. 25, n. 1-2, p. 94-98, jan.-dez. 2003.

MONARETTO, V. A vibrante pós-vocálica em Porto Alegre. In: BISOL, L.;

BRESCANCINI, C. (Org.). Fonologia e variação: recortes do português brasileiro. Porto Alegre: EDIPUCRS, 2002. p. 253-268.

MOTA, J.; CARDOSO, S. A. M. Variação fônica nas capitais brasileiras. In: MARTINS, M. A.; ABRAÇADO, J.; (Ed.). Panorama sociolinguístico do português do Brasil. São Paulo: Contexto, 2015. p. 65-78.

NASCENTES, A. O linguajar carioca. 2. ed. Rio de Janeiro: Simões, 1953.

NASCIMENTO SILVA, A. As pretônicas no falar teresinense. 2009. 235 f. Tese (Doutorado em Letras) - Pontifícia Universidade Católica, Porto Alegre, 2009.

NESPOR, M.; VOGEL, I. Prosodic phonology. Berlin: Mouton De Gruyter, 2007.

OLIVEIRA, M. A. The neogrammarian controversy revisited. International Journal of the sociology of language, Berlin, v. 89, p. 93-105, 1991.

PÄHLSSON, C. The Northumbrian Burr. Lund: Berlingska Boktryckeriet Lund, 1972. RAZKY, A. Atlas Linguístico Sonoro do Pará - ALiSPA 1.1. CD-ROM. Windows, 2004. RAZKY, A; SANTOS, E.G. O perfil geolinguístico da vogal /e/ no estado do Pará. In: RIBEIRO, S. S. C; COSTA, S. B. B.; CARDOSO, S. A. M. (Org.). Dos sons às palavras: nas trilhas da língua portuguesa. Salvador: EDUFBA, 2009. p. 17-39.

ROCHA, F. de M. V. O comportamento das vogais médias pretônicas na fala de Nova Iguaçu. 2013. 224 f. Dissertação (Mestrado em Letras Vernáculas) - Universidade Federal do Rio de Janeiro, Rio de Janeiro, 2013.

ROCHA, F. de M. V.; BRANDÂO, S. F. Vogais médias pretônicas na fala da Região Sudeste: um panorama geo-sociolinguístico. SIGNUM: Estudos Linguísticos, Londrina, v. 18, n. 1, p. 333-364, jun. 2015.

SERRA, C. R.; CALLOU, D. M. I. Prosodic structure, prominence and $/ \mathrm{r} /$-deletion in final coda position: Brazilian Portuguese and European Portuguese contrasted. In: DE DOMINICIS, A. (Org.). pS-prominenceS: Prominences in Linguistics International Conference. Viterbo: Disucom Press, 2015. p. 96-113.

SILVA, M. B. Um traço regional na fala culta de Salvador. Organon, v. 18, p. 79-89, 1991. . Pretônicas fechadas na fala culta de Recife. In: VOTRE, S.; RONCARATI, C. (Org.). Anthony Julius Naro e a linguística no Brasil: uma homenagem acadêmica. Rio de Janeiro: 7Letras, 2008. p. 320-336. 
SILVEIRA, A. A. M. As vogais pretônicas na fala culta do noroeste paulista. 2008. 143

f. Dissertação (Mestrado em Estudos Linguísticos) - Universidade Estadual Paulista “Júlio de Mesquita Filho", São José do Rio Preto, 2008.

SOARES, A. S. As pretônicas médias em comunidades rurais do semi-árido baiano. 2004. 137 f. Dissertação (Mestrado em Letras) -Universidade Federal da Bahia, Salvador, 2004.

SOARES, M. B. P. Normas de pronúncia radiofônica no Rio de Janeiro. Rio de Janeiro: UFRJ: Museu Nacional, 1977.

VIANNA, A. R. G. Essai de phonétique et de phonologie de la langue portugaise d'après de dialecte actuel de Lisbonne. Lisboa: Imprensa Nacional, 1883. . Portugais. Leipzig: Teubner, 1902.

VOTRE, S. Variação fonológica no Rio de Janeiro. 1978. Tese (Doutorado em Linguística) - Pontifícia Universidade Católica, Rio de Janeiro, 1978.

YACOVENCO, L. C. As vogais médias pretônicas na fala culta carioca. 1993. 185 f. Dissertação (Mestrado em Letras) - Universidade Federal do Rio de Janeiro, Rio de Janeiro, 1993. 